\title{
Application and research of fuzzy clustering analysis algorithm under "micro-lecture" English teaching mode
}

\author{
Ying Shi, Wei Dong, Chunyi Lou \& Yan Ding \\ Qinhuangdao Institute of Technology, Qinhuangdao, Hebei, China
}

\begin{abstract}
The fuzzy clustering algorithm is to classify the data or indicators with a greater degree of similarity based on the principle of the same type of individuals possessing a greater similarity, and different types of individuals possessing differences, establish clear category boundaries, form any shape of relationship clusters in the solving process, and input the research indicators at random, in order to accurately analyze the significance of the indicators in the algorithm. The evaluation value of the clustering analysis can be obtained by the establishment of the fuzzy factor set based on the membership analysis, and the evaluation result can be analyzed through reference to the evaluation indicators of the fuzzy clustering analysis. The "micro-lecture" English teaching mode can be estimated and the analysis indicators can be rationally established based on the fuzzy clustering analysis algorithm, with better algorithm applicability.
\end{abstract}

Keywords: micro-lecture; fuzzy clustering; teaching mode; flipped learning

\section{INTRODUCTION}

"Micro-lecture" is a new teaching mode. For the understanding of "micro-lecture", it mainly has the following viewpoints. Some scholars believe that the "micro-lecture" mode is a basic course, which serves for blended learning, flipped learning and a variety of learning styles; Hu Tiesheng and other scholars believe that "micro-lecture" teaching can be viewed as a kind of network video course, and become a part of teaching design; Jiao Jianli and other scholars believe that, as a kind of English teaching resource, the online education is subject to dapper online video, and aims at realizing the course scenario, digitization and interest. Based on the above analysis, the "micro-lecture" English teaching is based on the video as the main teaching medium. Each micro lecture is a complete teaching based on a knowledge point or a concept. "Micro-lecture" video can be from the network resources, and can also be produced or recorded by the English teachers. It is mainly subject to the platform of network, so that the students can implement free leaning through mobile devices. Of course, the micro-lecture video can be added in the ordinary classroom teaching, in order to improve the teaching quality.

\section{FUZZY CLUSTERING ANALYSIS UNDER "MICRO-LECTURE" ENGLISH TEACHING MODE}

The main form of micro-lecture applied in college English teaching based on the establishment of the factor set is $U_{1}$; the scope of content selection of college English micro-lecture is $U_{2}$; the development strategy of micro-lecture in college English teaching is $U_{3}$; the characteristic of micro-lecture in college English teaching is $U_{4}$; the path analysis of micro-lecture and college English teaching is $U_{5}$ :

$$
U=\left(U_{1}, U_{2}, U_{3}, U_{4}, U_{5}\right)
$$

The fuzzy clustering analysis indicators are established according to five main factor sets, as shown in Table 1.

\section{FUZZY CLUSTERING ANALYSIS ALGORITHM UNDER "MICRO-LECTURE" ENGLISH TEACHING MODE}

(1) To determine the factor domain in the process of modeling: 
Table 1. Fuzzy clustering analysis indicators

\begin{tabular}{|c|c|c|c|c|}
\hline $\begin{array}{l}\text { Main form of micro-lecture } \\
\text { applied in college English } \\
\text { teaching } U_{1}\end{array}$ & $\begin{array}{l}\text { Scope of content selec- } \\
\text { tion of college English } \\
\text { micro-lecture } U_{2}\end{array}$ & $\begin{array}{l}\text { Development strategy of } \\
\text { micro-lecture in college } \\
\text { English teaching } U_{3}\end{array}$ & $\begin{array}{l}\text { Characteristic of mi- } \\
\text { cro-lecture in college } \\
\text { English teaching } U_{4}\end{array}$ & $\begin{array}{l}\text { Path analysis of mi- } \\
\text { cro-lecture and college } \\
\text { English teaching } U_{5}\end{array}$ \\
\hline $\begin{array}{l}\text { Micro-lecture teaching in } \\
\text { general English classroom } \\
u_{11}\end{array}$ & $\begin{array}{l}\text { Phonological knowledge } \\
u_{21}\end{array}$ & $\begin{array}{l}\text { Integration and conver- } \\
\text { gence of micro-lecture } \\
\text { and traditional English } \\
\text { classroom teaching } u_{31}\end{array}$ & $\begin{array}{l}\text { Enhancement of stu- } \\
\text { dents interest in Eng- } \\
\text { lish learning } u_{41}\end{array}$ & $\begin{array}{l}\text { English micro-lecture } \\
\text { resources } u_{51}\end{array}$ \\
\hline $\begin{array}{l}\text { Students independent learn- } \\
\text { ing environment outside the } \\
\text { classroom } u_{12}\end{array}$ & $\begin{array}{l}\text { Syntax, semantic } \\
\text { knowledge } u_{22}\end{array}$ & $\begin{array}{l}\text { Professional business level } \\
\text { of English teachers } u_{32}\end{array}$ & $\begin{array}{l}\text { Freedom and flexible } \\
\text { learning time of mi- } \\
\text { cro-lecture } u_{42}\end{array}$ & $\begin{array}{l}\text { Change of educational } \\
\text { concept and attempt of } \\
\text { flipped classroom } u_{52}\end{array}$ \\
\hline \multirow[t]{2}{*}{$\begin{array}{l}\text { Listening and speaking } \\
\text { practices or "English cor- } \\
\text { ner" and other related prac- } \\
\text { tical activities } u_{13}\end{array}$} & $\begin{array}{l}\text { Text structure } \\
\text { knowledge } u_{23}\end{array}$ & $\begin{array}{l}\text { Media Network operating } \\
\text { skills } u_{33}\end{array}$ & $\begin{array}{l}\text { Dapper micro-lecture } \\
u_{43}\end{array}$ & $\begin{array}{l}\text { Introduction of sup- } \\
\text { porting policies and } \\
\text { encouragement of the } \\
\text { teachers and students } \\
\text { to make micro-lecture } \\
u_{53}\end{array}$ \\
\hline & $\begin{array}{l}\text { English micro-lecture } \\
\text { skills } u_{24} \\
\text { Non-language } \\
\text { knowledge } u_{25}\end{array}$ & $\begin{array}{l}\text { Facilities, platforms and } \\
\text { resources applied in mi- } \\
\text { cro-lecture } u_{34}\end{array}$ & $\begin{array}{l}\text { Targeted and top- } \\
\text { ic-focused mi- } \\
\text { cro-lecture } u_{44}\end{array}$ & \\
\hline
\end{tabular}

$U=\left\{u_{1}, u_{2}, \cdots, u_{n}\right\}$

(2) To determine the evaluation domain:

$V=\left\{v_{1}, v_{2}, \cdots, v_{m}\right\}$

(3) To determine the fuzzy evaluation matrix $R=\left(r_{i j}\right)_{n \times m}$ :

$R=\left[\begin{array}{cccc}r_{11} & r_{12} & \cdots & r_{1 n} \\ r_{21} & r_{22} & \cdots & r_{2 n} \\ \vdots & \vdots & & \vdots \\ r_{m 1} & r_{m 2} & \cdots & r_{m n}\end{array}\right]$

The evaluation $f\left(u_{i}\right)(i=1,2, \ldots, n)$ can be made for each factor $u_{i}$, so as to obtain a fuzzy mapping $f$ from the factor domain $U$ to the evaluation domain $V$, namely:

$$
\begin{aligned}
f: U & \rightarrow F(U) \\
u_{i} & \mapsto f\left(u_{i}\right)=\left(r_{i 1}, r_{i 2}, \cdots, r_{i m}\right) \in F(V)
\end{aligned}
$$

Then, to find out the fuzzy relation $R_{f} \in F(U \times V)$ from the fuzzy mapping $f$, namely:

$R_{f}\left(u_{i}, v_{j}\right)=f\left(u_{i}\right)\left(v_{j}\right)=r_{i j}(i=1,2, \cdots, n ; j=1,2, \cdots, m)$

(4) To establish a weight set, $A=\left(a_{1}, a_{2}, \ldots, a_{n}\right) \in F(U)$, boundary conditions:

$\sum_{i=1}^{n} a_{i}=1 \quad a_{i} \geq 0$
$B=A \cdot R$

$$
\begin{aligned}
& =\left(a_{1}, a_{2}, a_{3}, \cdots, a_{n}\right) \cdot\left[\begin{array}{cccc}
r_{11} & r_{12} & \cdots & r_{1 n} \\
r_{21} & r_{22} & \cdots & r_{2 n} \\
\vdots & \vdots & & \vdots \\
r_{m 1} & r_{m 2} & \cdots & r_{m n}
\end{array}\right] \\
& =\left(b_{1}, b_{2}, b_{3}, \cdots, b_{n}\right)
\end{aligned}
$$

(5) To evaluate the fuzzy clustering

For the weight $A=\left(a_{1}, a_{2}, \ldots, a_{n}\right) \in F(U)$, the model $M(\wedge, \vee)$ can be used for maximum - minimum compositional operation, thus obtaining comprehensive evaluation:

$$
B=A \circ R \quad\left(\Leftrightarrow b_{j}=\bigvee_{i=1}^{n}\left(a_{i} \wedge r_{i j}\right), j=1,2, \cdots, m\right)
$$

The determination of the weight $A=\left(a_{1}, a_{2}, \ldots, a_{n}\right)$ of the evaluation set $V$ is an important part in the process of modeling. The main reason is that, in the evaluation process, the determination is made through the establishment of the fuzzy relation from reality. The fuzzy comprehensive evaluation model selected in the process of modeling is $(U, V, R)$. For the weight $A=\left(a_{1}, a_{2}, \ldots, a_{n}\right) \in F(U)$, the fuzzy evaluation matrix is $R=\left(r_{i j}\right)_{n \times m}$. The model $M(\wedge, \vee)$ can be used to obtain the comprehensive evaluation process:

$B=A \circ R=\left(b_{1}, b_{2}, \cdots, b_{m}\right) \in F(V)$,

where: $b_{j}=\bigvee_{i=1}^{n}\left(a_{i} \wedge r_{i j}\right) \quad(j=1,2, \cdots, m)$. 


$$
b_{j}=\bigvee_{i=1}^{n}\left(a_{i} \wedge r_{i j}\right) \quad(j=1,2, \cdots, m)
$$

The evaluation set can be obtained by the above fuzzy clustering algorithm.

$U_{1}=\left\{u_{11}, u_{12}\right\}$

$U_{2}=\left\{u_{21}, u_{22}, u_{23}, u_{24}\right\}$

$U_{3}=\left\{u_{31}, u_{32}, u_{33}, u_{34}, u_{35}\right\}$

$U_{4}=\left\{u_{41}, u_{42}, u_{43}, u_{44}\right\}$

$U_{5}=\left\{u_{51}, u_{52}, u_{53}\right\}$

In the process of modeling, the following five ranking matrixes can be obtained: the main form of micro-lecture applied in college English teaching $U_{1}$, the scope of content selection of college English micro-lecture $U_{2}$, the development strategy of micro-lecture in college English teaching $U_{3}$, the characteristic of micro-lecture in college English teaching $U_{4}$, the path analysis of micro-lecture and college English teaching $U_{5}$.

In this paper, the weight factor fuzzy set of a single-layer indicator is:

$U_{1}^{*}=\left\{U_{11}, U_{12}, U_{13}\right\}=\{0.25,0.55,0.2\} ;$

$U_{2}^{*}=\left\{U_{21}, U_{22}, U_{23}, U_{24}, U_{25}\right\}=\{0.25,0.55,0.2\} ;$

$U_{3}^{*}=\left\{U_{31}, U_{32}, U_{33}, U_{34}\right\}=\{0.54,0.1,0.24,0.14\} ;$

$U_{4}^{*}=\left\{U_{41}, U_{42}, U_{43}, U_{44}\right\}=\{0.24,0.31,0.22,0.23\}$

$U_{5}^{*}=\left\{U_{51}, U_{52}, U_{53}\right\}=\{0.3,0.43,0.27\}$

The weight vector obtained from the evaluation process:

$$
\begin{aligned}
& \beta=\left\{\beta_{1}, \beta_{2}, \beta_{3}, \beta_{4}, \beta_{5}\right\}=\{0.3,0.3,0.2,0.1,0.1\} \\
& U_{i}^{*}=U_{i} \cdot \beta^{T} \\
& U_{1}^{*}=10, U_{2}^{*}=9.4, U_{3}^{*}=5.6, U_{4}^{*}=4, U_{5}^{*}=4
\end{aligned}
$$

After normalization,

$U_{1}^{*}=0.303, \quad U_{2}^{*}=0.285, U_{3}^{*}=0.170, U_{4}^{*}=0.121$, $U_{5}^{*}=121$

Thus
Based on $\bar{A}=\left(\begin{array}{lllll}0.28 & 0.25 & 0.21 & 0.13 & 0.13\end{array}\right)$, five clustering factor sets under the micro-lecture English teaching mode can be analyzed: the main form of micro-lecture applied in college English teaching, the scope of content selection of college English micro-lecture, the development strategy of micro-lecture in college English teaching, the characteristic of micro-lecture in college English teaching, proportion of path analysis of micro-lecture and college English teaching, and the corresponding weight value. The weight value and impact of the main form of micro-lecture applied in college English teaching is the maximum.

This paper establishes the evaluation membership, as shown in Table 2 .

Table 2. Fuzzy clustering analysis evaluation indicators

\begin{tabular}{lllll}
\hline \multirow{2}{*}{ Evaluation method } & \multicolumn{4}{l}{ Score range } \\
\cline { 2 - 5 } & $0-60$ & $60-80$ & $80-90$ & $90-100$ \\
\hline Very good & 0 & 0 & 0.05 & 0.95 \\
Good & 0 & 0.05 & 0.9 & 0.05 \\
General & 0.05 & 0.9 & 0.05 & 0 \\
Bad & 0.95 & 0.05 & 0 & 0 \\
\hline
\end{tabular}

For the establishment of secondary indicators, the process is complex. The experience-based judgment is made for the micro-lecture English teaching according to the research data and literature and cases, and the importance degree of the secondary indicators is reflected based on the size of the score. In this model, the secondary indicators are determined by reference to the domestic and foreign literatures, thus obtaining the clustering evaluation value of the micro-lecture English teaching.

The above analysis indicators can be used to obtain Table 3.

The evaluation sets of five main factors are obtained from application of micro-lecture in college English teaching:

Main form of micro-lecture applied in college English teaching:

$U_{1}=\left(\begin{array}{cccc}0 & 0 & 0.05 & 0.95 \\ 0 & 0.05 & 0.9 & 0.05 \\ 0 & 0.05 & 0.9 & 0.05\end{array}\right)$

Scope of content selection of college English micro-lecture:

$U_{2}=\left(\begin{array}{cccc}0 & 0 & 0.05 & 0.95 \\ 0 & 0 & 0.05 & 0.95 \\ 0 & 0.05 & 0.9 & 0.05 \\ 0 & 0 & 0.05 & 0.95 \\ 0 & 0.05 & 0.9 & 0.05\end{array}\right)$

Development strategy of micro-lecture in college 
Table 3. Fuzzy clustering evaluation value under "micro-lecture" English teaching mode

\begin{tabular}{|c|c|c|c|}
\hline Each indicator, & Value & Each indicator & Value \\
\hline Micro-lecture teaching in general English classroom $u_{11}$ & Very good & Media network operating skills $u_{33}$ & Good \\
\hline $\begin{array}{l}\text { Students independent learning environment outside the } \\
\text { classroom } u_{12}\end{array}$ & General & $\begin{array}{l}\text { Facilities, platforms and resources applied in } \\
\text { micro-lecture } u_{34}\end{array}$ & Good \\
\hline $\begin{array}{l}\text { Listening and speaking practices or "English corner" } \\
\text { and other related practical activities } u_{13}\end{array}$ & Very good & $\begin{array}{l}\text { Enhancement of students interest in English } \\
\text { learning } u_{41}\end{array}$ & Good \\
\hline Phonological knowledge $u_{21}$ & Very good & $\begin{array}{l}\text { Freedom and flexible learning time of mi- } \\
\text { cro-lecture } u_{42}\end{array}$ & General \\
\hline Syntax, semantic knowledge $u_{22}$ & General & Dapper micro-lecture $u_{43}$ & Good \\
\hline Text structure knowledge $u_{23}$ & Very good & Targeted and topic-focused micro-lecture $u_{44}$ & General \\
\hline English micro-lecture skills $u_{24}$ & General & English micro-lecture resources $u_{51}$ & General \\
\hline Non-language knowledge $u_{25}$ & Good & $\begin{array}{l}\text { Change of educational concept and attempt of } \\
\text { flipped classroom } u_{52}\end{array}$ & Good \\
\hline $\begin{array}{l}\text { Integration and convergence of micro-lecture and tradi- } \\
\text { tional English classroom teaching } u_{31}\end{array}$ & General & $\begin{array}{l}\text { Introduction of supporting policies and en- } \\
\text { couragement of the teachers and students to } \\
\text { make micro-lecture } u_{53}\end{array}$ & Good \\
\hline Professional business level of English teachers $u_{32}$ & General & & \\
\hline
\end{tabular}

English teaching:

$U_{3}=\left(\begin{array}{cccc}0 & 0 & 0.05 & 0.95 \\ 0 & 0 & 0.05 & 0.95 \\ 0 & 0 & 0.05 & 0.95 \\ 0 & 0.05 & 0.9 & 0.05\end{array}\right)$

Characteristic of micro-lecture in college English teaching:

$$
U_{4}=\left(\begin{array}{cccc}
0 & 0 & 0.05 & 0.95 \\
0 & 0 & 0.05 & 0.95 \\
0 & 0 & 0.05 & 0.95 \\
0 & 0.05 & 0.9 & 0.05
\end{array}\right)
$$

Path analysis of micro-lecture and college English teaching:

$U_{5}=\left(\begin{array}{cccc}0 & 0 & 0.05 & 0.95 \\ 0 & 0.05 & 0.9 & 0.05 \\ 0 & 0.05 & 0.9 & 0.05\end{array}\right)$

According to the formula

$B_{i}=A_{i} \cdot R_{i}$

The fuzzy evaluation matrix can be obtained by the normalization processing of $B_{i}$.

$\bar{B}=\left(\begin{array}{l}B_{1} \\ B_{2} \\ B_{3} \\ B_{4} \\ B_{5}\end{array}\right)=\left(\begin{array}{cccc}0.07 & 0.26 & 0.14 & 0.41 \\ 0 & 0.16 & 0.74 & 0.54 \\ 0.14 & 0.14 & 0.31 & 0.17 \\ 0.16 & 0.21 & 0.31 & 0.34 \\ 0.11 & 0.32 & 0.26 & 0.31\end{array}\right)$

The evaluation value is obtained based on the fuzzy clustering analysis algorithm:
$Z=U^{*} \cdot B=\left(\begin{array}{llll}0.38 & 0.33 & 0.10 & 0.19\end{array}\right)$

In the evaluation value $Z, 0.38>0.33>0.1>0.19$. By reference to the evaluation indicators of the fuzzy clustering analysis, the maximum values in $Z$ is corresponding to the evaluation indicators of 90-100. The result shows that the "micro-lecture" obtains a better evaluation in English teaching mode, and its application prospects and improved teaching effect are also obvious.

\section{CONCLUSION}

With the continuous deepening of the micro-lecture education, the educational pattern can increase the students' interest in English learning, and enhance students' independent learning ability. This paper carious out the fuzzy clustering based on the similarity of indicators, and form any shape of relationship clusters, and input the research indicators at random, in order to accurately analyze the applicability of the micro-lecture English teaching mode.

\section{REFERENCES}

[1] Hu Tiesheng, Huang Mingyan, Li Min. 2013. Three stages of China's micro-lecture development and its implications. Distance Education, (4): 36-42.

[2] Hu Tiesheng, Zhou Xiaoqing. 2014. Status analysis and research on the development strategy of the college micro-lecture construction. Modern Educational Technology, (2): 5-13.

[3] Zhang Chunping. 2014. Exploration of reform of higher vocational college talent training based on "MOOC". Communication of Vocational Education, (17): 10-12.

[4] Jiao Jianli. 2013. Micro-lecture and its application and impact. Information Technology of Primary and Secondary Schools, (4): 13-14. 
[5] Shao Hua. 2014. Research on higher vocational college classroom teaching mode reform guided by micro-lecture concept. Adult Education, 34 (5): 99-101.

[6] Wang Li. 2014. Discussion of higher vocational college English "micro-lecture" teaching strategies. Reading,
Writing, Arithmetic (Education and Teaching Research), (17): 339.

[7] Yang Shufang. 2005. Fuzzy Multiple Attribute Decision Making Method and its Applied Research. Jiangmen: Wuyi University. 